\title{
Fractionation of Pig Gastric Mucosa and the Properties particularly Antigenicity of the High-molecular Components separated
}

\author{
Second Paper* \\ By \\ Kohsiroh Tokutomi \\ (德富 紅紫郎) \\ From the Medico-chemical Institute (Director: Prof. H. Masamune) \\ and the Forensic Medical Institute (Director: Prof. T. Murakami), \\ Tohoku University, Sendai \\ (Received for publication, July 3, 1953) \\ Rabbit antiserum of gastric mucosa, liver and kidney cortex of pig \\ and gastric mucosa of dog (physiological saline extracts) were prepared \\ and the serological reactivity of the high molecular components of pig \\ stomach mucosa, which had been previously reported ${ }^{11}$, with the sera, \\ as such and after absorption with pig serum and one of the extracts of the \\ tissues above and mucosa of portions of the pig digestive tract other \\ than stomach, was examined. The results indicated that the pentose- \\ nucleic acid of stomach mucosa is extremely organ-specific, if not strictly, \\ contrary to the other components of the same tissue, which, though, \\ are not devoid of somewhat characteristic feature.
}

\section{EXPERIMENTAL}

\section{Methods}

I. Immune sera

1. Immunization method in general

a) A tissue or an organ mechanically freed from adjacent tissues (mucus, membranes, blood vessels or others) was washed for a short time under running water and wiped with filter paper. It was then minced, ground, and shaken with 10 volumes of physiological saline (Some toluene was added as a preservative) for 3 days. The residue was rejected by percolation and subsequent filtration in an ice chamber. The filtrate was dialyzed in a cellophane bag against running water for 3-5 days, and after filtering off the appearing sediment, the clear filtrate

\footnotetext{
* The 2nd report of Masamune and coworkers' "Nucleic Acids."
} 
was preserved in a brown bottle with $1 / 10-1 / 20$ volume of $5 \%$ phenol after addition of $\mathrm{NaCl}$ to $0.85 \%$ in the mixture.

b) To a male rabbit of about $2.5 \mathrm{~kg}$. were injected intravenously 3-7 cc. of an antigen solution, prepared as above, every 3 days. The injection was repeated 5-8 times and after 4-7 days from the last injection (The antigen titre was found mostly 500 (maximum dilution in terms of times of the immunogen solution where precipitin reaction occurred) and the antibody titre 8-16 (the corresponding dilution of the antiserum)), the animal was deprived of food for 1 day to shed blood from carotid artery. The serum was separated in a usual manner after standing the blood in an incubator of $37^{\circ} \mathrm{C}$ for 30 minutes and in an ice chamber overnight. It was inactivated by exposing to $56^{\circ} \mathrm{C}$ for 30 minutes and after addition of $1 / 9$ volume of $5 \%$ phenol containing $0.85 \% \mathrm{NaCl}$, preserved in an ice chamber as sealed in a brown ampoule.

\section{Anti-pig gastric mucosa-sera}

The immunogen solution. The mucosa was teared off from the muscle layer and after freeing from the mucus, empolyed as a material. Of the solution (prior to addition of phenol), $100 \mathrm{cc}$. were distilled in vacuo to a syrup and dehydrated with alcohol. The insoluble weighed $154 \mathrm{mg}$., when dried in vacuo over $\mathrm{CaCl}_{2}$.

Six antisera prepared were of antigen titre of 512 and of antibody titre of 16 or 32 .

3. Anti-pig liver-sera

An immunogen solution prior to addition of phenol, which had been prepared as above, was found to contain $0.19 \%$ alcohol-insoluble components, as measured as in 2. The immune serum had antigen and antibody titre of 512 and 8 respectively-anti-pig liver-serum I.

Here another antiserum was also prepared, by employing an antigen solution obtained without dialysis. This solution was markedly biuretand Molisch-positive, fairly Bial-Mejbaum- and Dische-positive and contained phosphorus and purine. The alcohol-insoluble components of it amounted to $0.32 \%$. The immune serum had antigen and antibody titre of 2048 and 32 respectively-Anti-pig liver-serum II.

4. Anti-pig kidney cortex-sera

The immunogen solution obtained showed similar results in testtube tests as the solution used for obtaining Anti-pig liver-serum II and contained $0.23 \%$ alcohol-insoluble components. Either of two antisera given had an antigen titre of 520 and an antibody titre of 32 .

5. Anti-canine stomach mucosa-sera

The canine stomach mucosa, wherefrom the mucus had been scraped off, was used as the material to prepare the immunogen solution. The antigen solution immediately after dialysis contained $0.19 \%$ the alcohol- 
insoluble. It resembled the corresponding solution in 4. chemical-qualitatively, but was almost Dische-negative. One of two antisera prepared (I) had antigen titre 5000 and antibody titre 32 and the other (II) the corresponding titres of 2500 and of 16 .

II. Serological reactions

1. Precipitin test

The ring test was processed in two ways by the $\alpha$ - and $\beta$-Marrack procedures at $37^{\circ} \mathrm{C}$. A $10 \mathrm{mg}$. portion of the in vitro antigens (reactionogens) (S. below) were dissolved in $1 \mathrm{cc}$. of physiological saline and further diluted with physiological saline progressively twofold. The antisera were diluted in most cases in a similar manner but with physiological saline containing $1.5 \%$ Arabic gum.

\section{Complement-fixing test}

This test was adapted for examining the antigenicity of the alcoholsoluble lipid components of the pig stomach mucosa.

The in vitro antigen (reactionogen). The pig stomach mucosa (ground) was maintained under 10 volumes of abs. denatured alcohol containing $3 \% \mathrm{CH}_{3} \mathrm{OH}$ in an incubator at $37^{\circ} \mathrm{C}$ for 1 week, with occasional agitation. The solution was separated and distilled in vacuo to a syrup and dried in a desiccator over $\mathrm{CaCl}_{2}$. From $50 \mathrm{~g}$. of the fresh material $5.6 \mathrm{~g}$. of the extract were given. Next, $5 \mathrm{~g}$. of it were dissolved in $100 \mathrm{cc}$. of abs. alcohol at $37^{\circ} \mathrm{C}$ which took 24 hours, followed by standing for several hours at room temperature $\left(18^{\circ} \mathrm{C}\right)$ wherby a precipitate occurred. The precipitate was filtered off and the filtrate ( $96 \mathrm{cc}$.) was distilled in vacuo to a thick paste, which was subjected to a similar purification procedure twice more. $2.4 \mathrm{~g}$. of a dry dark-brown putty-like substance were given-Cold-alcohol soluble fraction.

A $0.5 \%$ solution of the product in alcohol was applied as the original antigen solution, one of the anti-pig gastric mucosa-sera as the antiserum, a guinea-pig serum, diluted as to contain 2 complement units in 0.1 cc., as the complement solution, and a $2.5 \%$ beef erythrocyte suspension in an immune rabbit serum, possessing hemolysin titre 2400 and diluted, $(0.25 \mathrm{cc}$. of the hemolytic system contained 7 units $)$ as the hemolytic system. And the test was processed as follows: $0.25 \mathrm{cc}$. of the antigen solution diluted 40 or 30 times with physiological saline, $0.25 \mathrm{cc}$. of the antiserum, absorbed and progressively diluted, and $0.1 \mathrm{cc}$. of the complement solution were let combine together by standing at $37^{\circ} \mathrm{C}$ for 1 hour (shaken every 15 minutes), and after addition of the sensitized beef erythrocytes $(0.25 \mathrm{cc}$. of the suspension), further stood at the same temperature for the same duration of time (shaken every 15 minutes) to examine the occurrence of hemolysis.

3. Absorption of the antisera with in vitro antigens 
The absorption was made by adding a quantity of an in vitro antigen (See below) to a serum and standing the mixture at $37^{\circ} \mathrm{C}$ for 3 hours and overnight in an ice chamber. The precipitate was centrifuged off and the supernatant was examined whether or not complete absorption had been effected by addition of an additional portion of the antigen.

III. The in vitro antigens

\section{Whole-pig gastric mucosa-antigen}

The clear solution, obtained after extraction of the mucosa and dialysis in the manner in I, 1 , a), was condensed immediately, precipitated with alcohol, followed by washing with ether, and dried. The substance given was used as a whole as the in vitro antigen-Whole-pig stomach mucosa-antigen.

Besides, the high-molecular components which have been described in the first paper ${ }^{1)}$ and the alcohol-soluble above were employed as reactionogens from the same tissue.

2. Whole-antigen of the parts of the pig digestive tract other than stomach

The mucosa of the various parts of the digestive tract (oesophagus, duodenum, small intestine and colon) were separately treated as that of stomach to gain preparations comprising the physiological saline-extractible, alcohol-precipitable components-Whole-antigens.

3. Whole-pig kidney-antigen

The antigen corresponding to the Whole-pig stomach mucosa-antigen was prepared from the kidney cortex in a similar manner.

4. Whole-pig liver-antigen

The preparation corresponding to the stomach antigen in 1 . and the one obtained without dialysis were used.

5. Pig serum as an absorbent

Fresh normal pig serum was inactivated and after addition of $1 / 19$ volume of physiological saline containing $5 \%$ phenol, preserved in an ampoule.

6. Whole-canine gastric mucosa-antigen

A mixture of the physiological saline-soluble, alcohol-insoluble components corresponding to Whole-pig gastric mucosa-antigen was separated from the canine stomach mucosa.

\section{Results}

1. Serological reactions of a rabbit anti-pig gastric mucosa-serum with the extract of the pig tissues and the components of the pig gastric mucosa

a) The details of preciption reaction of the antiserum unabsorbed are illustrated in Tables I, II and III. The immune rabbit serum gave the reaction not only with any of the various tissue extracts but also with pig blood serum, whereas no natural antibodies of those extracts were 


\section{TABLE I}

Precipitin Reaction of Whole-Pig Gastric Mucosa-Antigen with the Anti-Pig Gastric Mucosa-Rabbit Serum, showing antigen titre of $1000 \times 10^{5}$ and antibody titre of $2^{5}$

- : negative reaction, \pm : faint $r_{v},+$ : definitely positive $r$.

\begin{tabular}{|c|c|c|c|c|c|c|c|c|c|}
\hline \multirow{2}{*}{$\begin{array}{c}\text { Ditution of } \\
\text { antiserum } \\
(n \text { in } \times 2 n)\end{array}$} & \multicolumn{9}{|c|}{ Dilution of antigen $(n$ in $\times 1000 \times 2 n$ ) } \\
\hline & 0 & 1 & 2 & 3 & 4 & 5 & 6 & 7 & $\infty$ \\
\hline 0 & + & + & + & + & + & + & \pm & - & - \\
\hline 1 & + & + & + & + & + & + & \pm & - & - \\
\hline 2 & + & + & + & + & + & + & \pm & - & - \\
\hline 3 & + & + & + & + & + & + & \pm & - & 一 \\
\hline 4 & + & + & + & + & + & \pm & - & - & - \\
\hline 5 & + & + & + & + & - & - & - & - & - \\
\hline 6 & - & - & - & - & - & - & - & - & - \\
\hline
\end{tabular}

\section{TABLE II}

Precipitin Reaction of the Various Whole-Antigens of Pig

Tissues with Anti-Pig Gastric Mucosa-Rabbit Serum

The anti-serum was used without dilution. - : negative reaction, \pm : faint $r ., \quad+$ : difinitely positive $r$.

\begin{tabular}{|c|c|c|c|c|c|c|c|c|c|}
\hline \multirow{2}{*}{$\begin{array}{l}\text { Whole-tissue-antigen } \\
\text { (name of pig tissue) }\end{array}$} & \multicolumn{9}{|c|}{ - Dilution of antigens $(n$ in $\times 1000 \times 2 n)$} \\
\hline & 0 & 1 & 2 & 3 & 4 & 5 & 6 & 7 & $\infty$ \\
\hline Stomach mucosa & + & + & + & + & + & + & \pm & - & - \\
\hline Oesophagus mucosa & + & + & + & + & + & + & \pm & - & - \\
\hline Duodenum mucosa & + & + & + & + & + & + & \pm & - & - \\
\hline Small-intestine mucosa & + & + & + & + & + & + & - & - & - \\
\hline Colon mucosa & + & + & + & + & + & + & - & - & - \\
\hline Liver & + & + & + & + & + & \pm & - & 一 & - \\
\hline Kidney cortex & + & + & + & + & + & + & - & - & - \\
\hline
\end{tabular}

detected in normal rabbit serum.

b) Precipitin reaction of the antiserum, absorbed with pig blood serum or with pig serum and one of the extract of the tissues other than the stomach mucosa, with the various tissue extracts. Since the rabbit antiserum had been found to be completely absorbed with 0.23 volume of the pig serum, 1/4 the volume of the latter was used for absorption in this and following cases. Table IV shows the results given by the antiserum absorbed with the pig serum alone. All the Wholeantigens showed positive reaction, the gastric mucosa naturally proving most powerful. The extract of the lower parts of the digestive tract 


\section{TABLE III}

Precipitin Reaction of Pig Serum, as an in vitro Antigen, with Anti-Pig Gastric Mucosa-Rabbit Serum

- : negative reaction, \pm : faint $r .,+$ : definitely positive $r$.

\begin{tabular}{c|cccccccccccccc}
\hline $\begin{array}{c}\text { Dilution of the } \\
\text { rabbit antiserum } \\
(\mathrm{n} \text { in } \times 2 \mathrm{n})\end{array}$ & \multicolumn{110}{c}{ Dilution of antigen $(\mathrm{n}$ in $\times 10 \times 2 \mathrm{n})$} \\
\hline 0 & 0 & 1 & 2 & 3 & 4 & 5 & 6 & 7 & 8 & 9 & 10 & 11 & 12 & $\infty$ \\
\hline 0 & + & + & + & + & + & + & + & + & + & + & + & + & - & - \\
2 & + & + & + & + & + & + & + & + & + & + & + & + & - & - \\
3 & + & + & + & + & + & + & + & + & + & + & + & + & - & - \\
4 & + & + & + & + & + & + & + & - & - & - & - & - & - & - \\
5 & + & + & + & + & + & + & + & - & - & - & - & - & - & - \\
& - & - & - & - & - & - & - & - & - & - & - & - & - & -
\end{tabular}

\section{TABLE IV}

Precipitin Reaction of the Various Whole-Antigens of Pig

Tissues with the Anti-Pig Gastric Mucosa-Rabbit

Serum, absorbed with Normal Pig Serum

The antiserum was used without dilution. - : negative reaction, \pm : faint $r .,+$ : definitely positive $r$.

\begin{tabular}{|c|c|c|c|c|c|c|c|c|c|c|c|c|}
\hline \multirow{3}{*}{$\begin{array}{l}\text { Whole-tissue-antigen } \\
\text { (name of pig tissue) }\end{array}$} & \multicolumn{12}{|c|}{ Dilution of antigens } \\
\hline & \multicolumn{4}{|c|}{$n$ in $\times 100 \times 2 n$} & \multicolumn{8}{|c|}{$\mathrm{n}$ in $\times 1000 \times 2 \mathrm{n}$} \\
\hline & 0 & 1 & 2 & 3 & 0 & 1 & 2 & 3 & 4 & 5 & 6 & $\infty$ \\
\hline Stomach mucosa & + & + & + & + & + & + & + & + & $(16) *$ & \pm & - & - \\
\hline Oesophagus mucosa & + & + & + & + & + & + & + & + & - & - & - & - \\
\hline Duodenum mucosa & + & + & + & + & + & + & + & - & - & - & - & - \\
\hline Small-intestine mucosa & + & + & + & + & + & \pm & - & - & - & - & - & - \\
\hline Colon mucosa & + & + & + & + & + & $一$ & - & - & - & - & - & 一 \\
\hline Liver & + & \pm & - & - & - & - & - & - & - & - & - & - \\
\hline Kidney cortex & + & + & \pm & - & - & - & - & - & - & - & - & - \\
\hline
\end{tabular}

* Antibody titre.

gave the reaction, with strengths decreasing with the increase of distance of the parts from stomach. The extracts from the liver and kidney also reacted though weak. The results embodied in Table V, which account for the precipitin reactions of the antiserum after double absorption with pig serum and one of the Whole-antigens, indicate that, when absorbed with the extract of the oesophagus besides the pig serum, the antiserum was able to give the reaction only with the Whole-stomach mucosaantigen, but, when the antiserum had been absorbed with the extract 


\section{TABLE V}

Precipitin Reaction of the Whole-Antigen of Various Pig Tissues with the Anti-Pig Gastric Mucosa-Rabbit Serum, double absorbed with Normal Pig Serum and One of the Whole-Antigens

The antiserum was used without dilution. - : negative reaction, \pm : faint $r .,+$ : definitely positive $r$.

\begin{tabular}{|c|c|c|c|c|c|c|c|c|c|c|c|}
\hline \multirow{3}{*}{$\begin{array}{l}\text { Whole-tissue-antigen } \\
\text { (name of pig tissue) }\end{array}$} & \multicolumn{11}{|c|}{ Dilution of antigens } \\
\hline & \multicolumn{4}{|c|}{$\mathrm{n}$ in $\times 100 \times 2 n$} & \multicolumn{7}{|c|}{$\mathbf{n}$ in $\times 1000 \times 2 n$} \\
\hline & 0 & 1 & 2 & 3 & 0 & 1 & 2 & 3 & 4 & 5 & $\infty$ \\
\hline \multicolumn{12}{|c|}{ Antiserum absorbed with } \\
\hline Stomach mucosa & + & + & + & + & + & + & $\stackrel{+}{(16)^{*}}$ & - & - & - & - \\
\hline Duodenum mucosa & - & - & - & - & - & $\ddot{-}$ & - & 二 & - & - & - \\
\hline $\begin{array}{l}\text { Small-intestine mucosa } \\
\text { Colon mucosa }\end{array}$ & - & $\underline{-}$ & - & $\overline{-}$ & $\overline{-}$ & $\overline{-}$ & - & $\overline{-}$ & $\bar{z}$ & $\overline{-}$ & $\overline{-}$ \\
\hline $\begin{array}{l}\text { Ciolon mucosa } \\
\text { Liver }\end{array}$ & - & $\overline{-}$ & $\overline{-}$ & - & - & - & - & - & - & - & - \\
\hline Kidney cortex & - & - & - & - & - & - & - & - & - & - & - \\
\hline
\end{tabular}

Antiserum absorbed with Whole-duodenum mucosa-antigen besides pig serum

Stomach mucosa

Oesophagus mucosa

Small-intestine mucosa

Colon mucosa

Liver

Kidney cortex

\begin{tabular}{|c|c|c|c|c|c|c|c|c|c|c|}
\hline+ & + & + & + & + & + & + & + & - & - & - \\
\hline+ & - & - & - & - & - & - & - & - & - & - \\
\hline+ & + & + & + & + & - & - & - & - & $\rightarrow$ & - \\
\hline+ & + & + & + & + & - & 一 & - & - & $I$ & $\overline{-}$ \\
\hline \pm & - & - & - & - & - & - & - & $=$ & 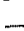 & - \\
\hline+ & \pm & & - & - & - & - & & & & \\
\hline
\end{tabular}

Antiserum absorbed with Whole-small-intestine mucosa-antigen besides pig serum

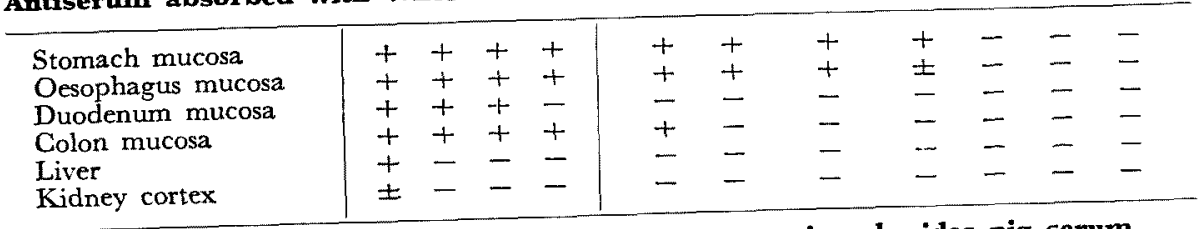

Antiserum absorbed with Whole-colon mucosa-antigen besides pig serum

\begin{tabular}{|c|c|c|c|c|c|c|c|c|c|c|c|}
\hline Stomach mucosa & + & + & + & + & + & + & + & + & + & - & - \\
\hline Oesophagus mucosa & + & + & + & + & + & + & $\begin{array}{l}+ \\
+\end{array}$ & 士 & - & - & - \\
\hline Duodenum mucosa & + & + & + & + & + & + & $\underline{-1}$ & - & - & - & - \\
\hline Small-intestine mucosa & + & + & + & + & 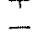 & 一 & - & - & - & 一 & 一 \\
\hline $\begin{array}{l}\text { Liver } \\
\text { Kidney cortex }\end{array}$ & \pm & $\overrightarrow{+}$ & - & - & - & - & 一 & - & - & - & 一 \\
\hline
\end{tabular}

Antiserum absorbed with Whole-liver-antigen besides pig serum

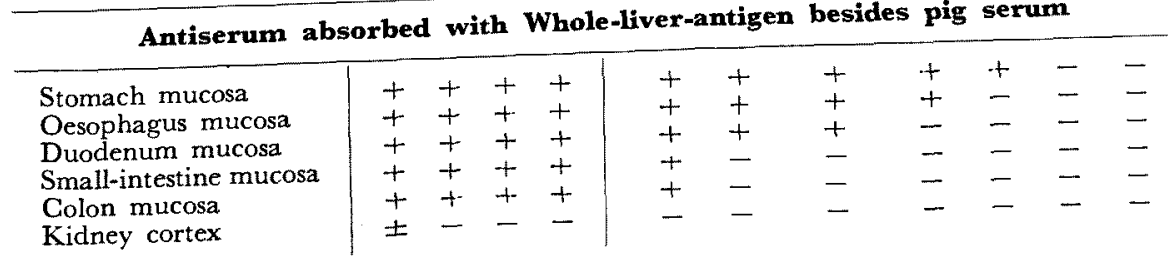


TABLE V (Continued)

\begin{tabular}{l|ccc|cc|cccccc}
\hline & \multicolumn{8}{|c}{ Dilution of antigens } \\
\cline { 2 - 9 } $\begin{array}{l}\text { Whole-tissue-antigen } \\
\text { (name of pig tissue) }\end{array}$ & $\mathrm{n}$ in $\times 100 \times 2 \mathrm{n}$ & \multicolumn{7}{c}{$\mathrm{n}$ in $\times 1000 \times 2 \mathrm{n}$} \\
\cline { 2 - 10 } & 0 & 1 & 2 & 3 & 0 & 1 & 2 & 3 & 4 & 5 & $\infty$ \\
\hline
\end{tabular}

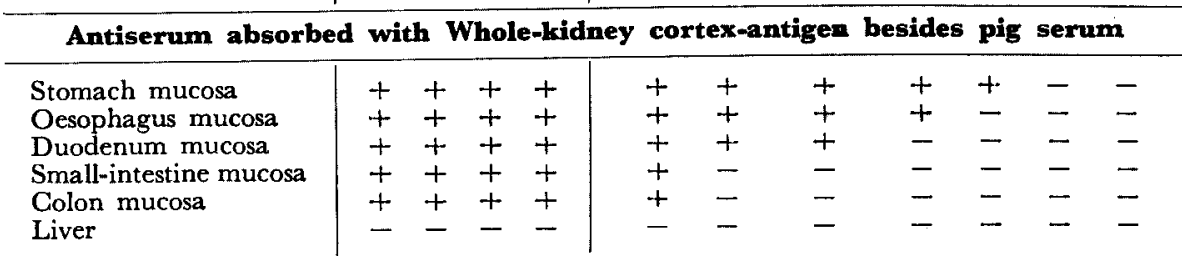

* Antibody titre.

of the mucosa of duodenum or small intestine or colon, there remained in it a pretty large amount of antibodies not only reactive with the Wholeantigen of stomach mucosa but also reactive with the antigens of the other tissues. The absorption with the extracts of liver and of kidney (cortex) effected no distinct influence.

c) The antiserum, absorbed with pig serum or successively with pig serum and one of the tissue extracts (Whole tissue-antigens) excepting the one of the stomach mucosa, was examined regarding the precipitin reaction with high molecular, water-soluble components of the gastric mucosa (Proteins I and II, the polyuronic acid mixture, the pentosenucleic acid and the group carbohydrate described in First Paper). The normal rabbit serum showed no precipitin reaction with any of the components. The results in Table VI illustrate: 1) the antiserum, absorbed with pig serum, reacted with all the stomach mucosa components remarkably; 2) Whole-oesophagus mucosa-antigen absorbed the antibody of all the stomach mucosa components other than the pentosenucleic acid; 3) the Whole-antigens of the other tissues could not entirely absorb the antibodies which Whole-oesophagus mucosa-antigen did, the degree of absorption lowering generally in the order below, the extract of the last tissue being the least effective, just resembling the relationship in the reaction between this antiserum and the Whole-tissue-antigens (See b)).

duodenum mucosa; small-intestine mucosa; colon mucosa; liver; kidney cortex

By none of those tissue extracts the antibody of the stomach pentosenucleic acid was absorbed.

d) The antigenicity of the cold-alcohol soluble fraction of the stomach mucosa was examined by the complement fixation (Regarding the technique, s. above). Table VIIA shows the minimum anti-comple- 


\section{TABLE VI}

Precipitin Reaction of Whole-Antigen and Components of Pig Stomach Mucosa with the Anti-Pig Gastric Mucosa-Rabbit Serum, absorbed with Normal Pig Serum or with Normal Pig Serum and one of the WholeAntigens of the Pig Tissues other than Stomach Mucosa

The antiserum was used without dilution. - : negative reaction, \pm : faint $r$., + : definitely positive $r$. Figures in parentheses express the antibody titre.

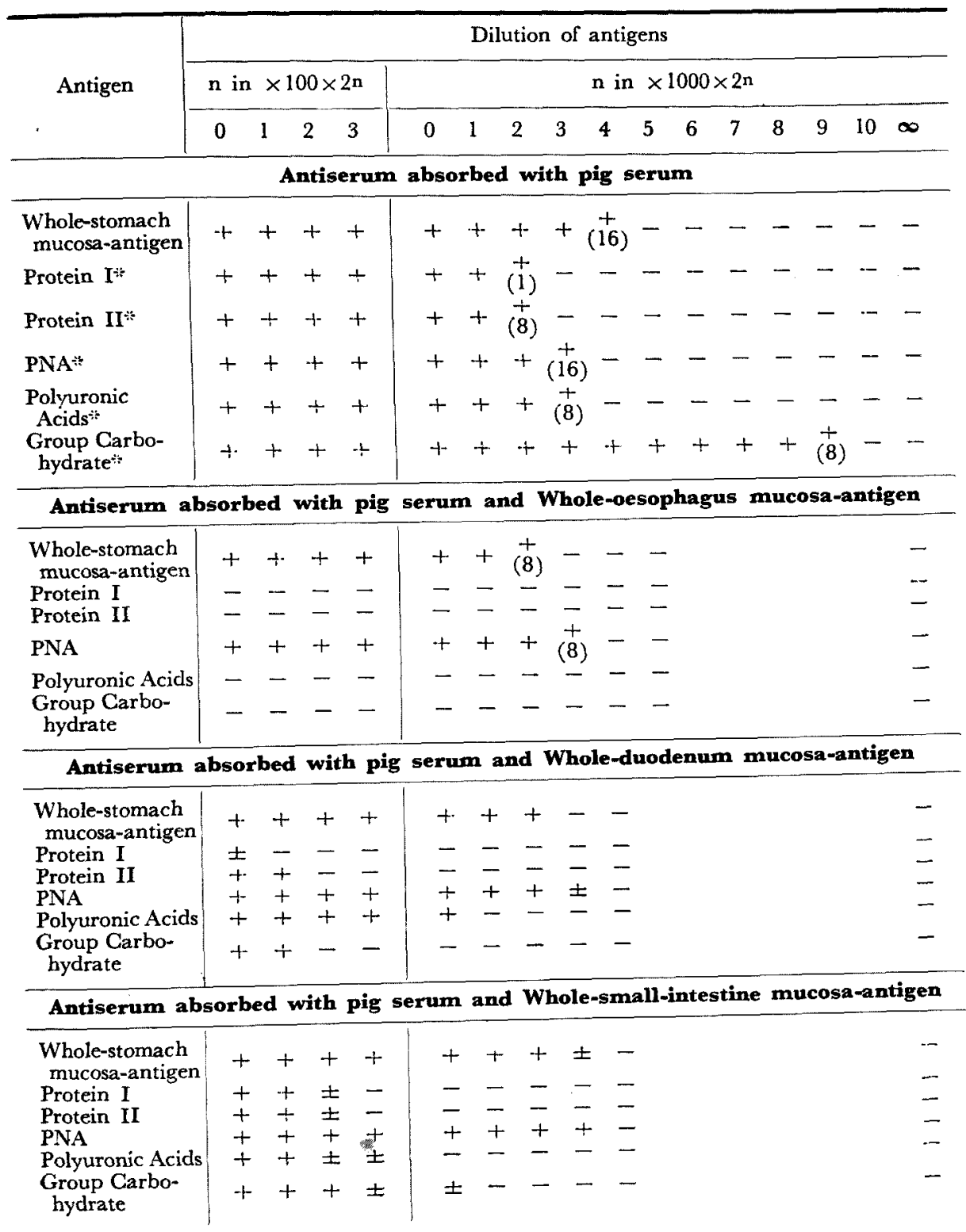


TABLE VI (Continued)

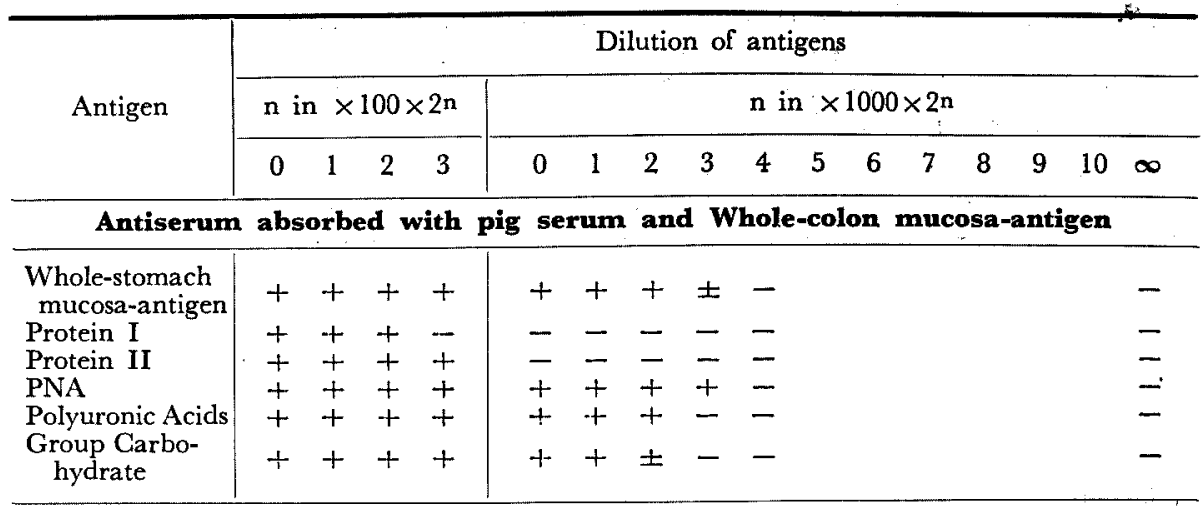

Antiserum absorbed with pig serum and Whole-liver-antigen

\begin{tabular}{|c|c|c|c|c|c|c|c|c|c|c|c|c|c|}
\hline $\begin{array}{l}\text { Whole-stomach } \\
\text { mucosa-antigen }\end{array}$ & + & + & + & + & + & + & + & + & \pm & - & - & 一 & - \\
\hline Protein I & + & + & + & \pm & 一 & - & 一 & - & - & - & - & - & - \\
\hline Protein II & + & + & + & + & + & + & + & - & 一 & - & - & - & - \\
\hline PNA & + & + & + & + & + & + & + & + & - & - & - & - & - \\
\hline Polyuronic Acids & + & + & + & + & + & + & - & - & - & - & - & - & - \\
\hline $\begin{array}{l}\text { Group Carbo- } \\
\text { hydrate }\end{array}$ & + & + & + & + & + & + & + & + & + & + & + & - & - \\
\hline
\end{tabular}

Antiserum absorbed with pig serum and Whole-kidney cortex-antigen

\begin{tabular}{|c|c|c|c|c|c|c|c|c|c|c|c|c|c|c|c|}
\hline $\begin{array}{l}\text { Whole-stomach } \\
\text { mucosa-antigen }\end{array}$ & + & + & + & + & + & + & + & + & 一 & - & 一 & - & $-m$ & - & 一 \\
\hline Protein I & + & + & + & + & $\longrightarrow$ & - & - & - & - & - & - & - & 一 & - & 一 \\
\hline Protein II & + & + & + & + & + & + & + & - & - & - & $\longrightarrow$ & $\longrightarrow$ & $\longrightarrow$ & - & 一 \\
\hline PNA & + & + & + & + & + & + & + & + & - & - & - & 一 & - & - & 一 \\
\hline Polyuronic Acids & + & + & + & \pm & - & 一 & - & - & - & - & - & 一 & - & - & - \\
\hline $\begin{array}{l}\text { Group Carbo- } \\
\text { hydrate }\end{array}$ & + & + & + & + & + & + & + & + & + & + & + & + & + & -- & $\cdots$ \\
\hline
\end{tabular}

* Cf. the First Paper.

mentary dose of the antigen itself. Since the antigen solution diluted more than 10 times gave rise to no hemolysis, it was diluted 30 and 40 times for the main test. Table VIIB demonstrates that, when absorbed with pig serum alone, the antiserum inhibited hemolysis, but not after further absorption with the Whole-oesophagus mucosa-antigen, so that the alcohol-soluble fraction of the stomach mucosa is considered to be able to form an antibody in rabbits, which, however, is not strictly specific to that tissue.

2. An anti-pig liver-serum did not give precipitin reaction with the highmolecular components of pig stomach mucosa

Anti-pig liver-serum II above was employed for the present assay. The precipitin reaction of the antiserum with whole-pig liver-antigen is illustrated in Table VIIIA. The antigen and antibody titre of the antiserum before absorption with pig serum were $1000 \times 2^{5}$ and $2^{5}$ respectively 


\section{TABLE VII}

A. Occurrence of Hemolysis when Cold-alcohol Soluble Fraction of the Pig Gastric Mucosa as an in vitro Antigen, Complement and Sensitized Erythrocytes were mixed together without Antibody

The test was processed as the complement-fixing test (S. text), replacing the diluted antiserum with physiological saline. - : no hemolysis, +: marked hemol., H: complete hemol.

\begin{tabular}{|c|c|c|c|c|c|c|c|c|c|c|c|}
\hline $\begin{array}{l}\text { Dilution of the original } \\
\text { antigen sol. (1: ) }\end{array}$ & 5 & 10 & 15 & 20 & 25 & 30 & 35 & 40 & 45 & 50 & $\infty$ \\
\hline Occurrence of hemolysis & - & 一 & H & H & \# & H & H & H & Ht & 卅 & $H$ \\
\hline
\end{tabular}

B. Complement-fixing Test of the Antigen in A. together with the Anti-Pig Gastric Mucosa-Serum

-: no hemolysis, +: slight hemol., H: marked hemol., H: complete hemol.

\section{i) The antiserum absorbed with pig serum}

The antigen and antibody titre of the absorbed antiserum in precipitin reaction with Whole-pig gastric mucosa-antigen were $1000 \times 2^{4}$ and $2^{4}$ respectively (See Table IV)

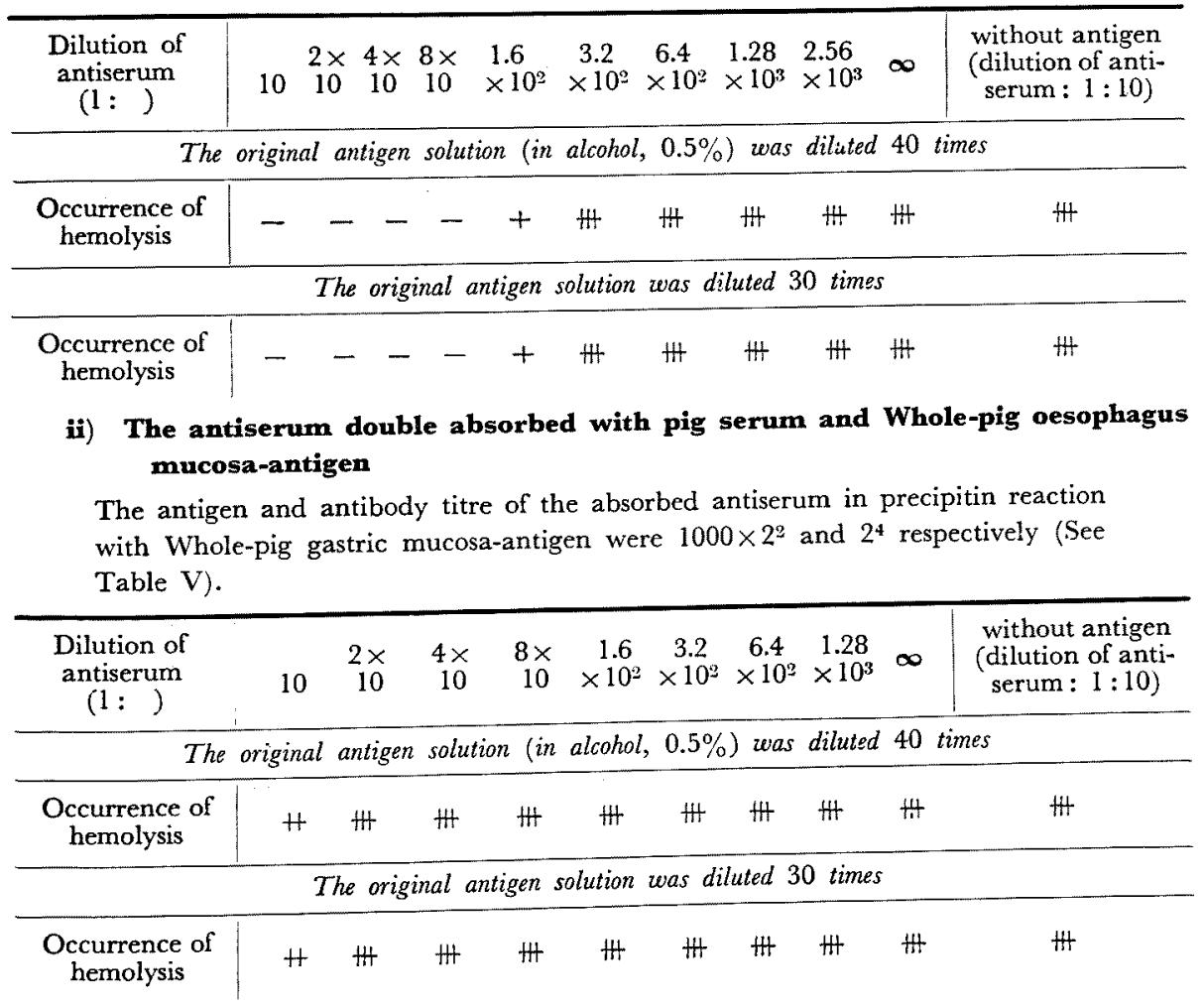




\section{TABLE VIII}

A. Precipitin Reaction of Anti-Pig Liver-Rabbit Serum with Whole-Pig Liver-Antigen

- : negative reaction, \pm : faint $r .,+$ : definitely positive $r$.

\begin{tabular}{|c|c|c|c|c|c|c|c|c|}
\hline \multirow{2}{*}{$\begin{array}{l}\text { Dilution of } \\
\text { antiserum } \\
(n \text { in } \times 2 n)\end{array}$} & \multicolumn{8}{|c|}{ Dilution of antigen $(n$ in $\times 1000 \times 2 n)$} \\
\hline & 0 & 1 & 2 & 3 & 4 & 5 & 6 & $\infty$ \\
\hline \multicolumn{9}{|c|}{ The antiserum not absorbed } \\
\hline 0 & + & + & + & + & + & + & - & - \\
\hline 1 & + & + & + & + & + & + & - & - \\
\hline 2 & + & + & + & + & + & + & - & - \\
\hline 3 & + & + & + & + & + & - & - & - \\
\hline 4 & + & + & + & + & + & - & - & - \\
\hline 5 & + & + & + & + & - & - & - & - \\
\hline 6 & \pm & \pm & - & - & - & - & - & - \\
\hline
\end{tabular}

\begin{tabular}{l|cccccccc}
\hline \multicolumn{7}{c}{ The antiserum absorbed with pig serum } \\
\hline 0 & + & + & + & + & + & - & - & - \\
1 & + & + & + & + & + & - & - & - \\
2 & + & + & + & + & + & - & - & - \\
3 & + & + & + & + & - & - & - & - \\
4 & + & + & + & + & - & - & - & - \\
5 & + & + & + & - & - & - & - & - \\
6 & - & - & - & - & - & - & - & -
\end{tabular}

B. The Reaction of the Same Antiserum, absorbed with Pig

Serum, with Whole-Antigen and Components of Pig Stomach Mucosa

The antiserum was used without dilution. - : negative reaction.

\begin{tabular}{|c|c|c|c|c|c|c|c|}
\hline \multirow{3}{*}{ Antigen } & \multicolumn{7}{|c|}{ Dilution of antigens } \\
\hline & \multicolumn{4}{|c|}{$\mathrm{n}$ in $\times 100 \times 2 \mathrm{n}$} & \multicolumn{3}{|c|}{$\mathrm{n}$ in $\times 1000 \times 2 \mathrm{n}$} \\
\hline & 0 & 1 & 2 & 3 & 0 & 1 & $\infty$ \\
\hline Whole-stomach mucosa-antigen & - & - & $\rightarrow$ & - & - & - & - \\
\hline Protein I & - & - & - & - & - & - & - \\
\hline Protein II & - & - & - & - & - & - & - \\
\hline PNA & - & - & - & - & - & - & - \\
\hline Polyuronic Acids & - & - & - & - & - & - & - \\
\hline Group Carbohydrate & - & - & - & - & - & - & - \\
\hline
\end{tabular}

and those after the absorption $1000 \times 2^{4}$ and $2^{5}$ respectively. The antiserum treated with pig serum gave the positive reaction neither with Whole-pig stomach mucosa-antigen nor with the separated components 


\section{TABLE IX}

A. Precipitin Reaction of Anti-Pig Kidney Cortex-Rabbit Serum with Whole-Pig Kidney Cortex-Antigen

- : negative reaction, \pm : faint $r$. + : definitely positive $\mathbf{r}$.

\begin{tabular}{|c|c|c|c|c|c|c|c|c|}
\hline \multirow{2}{*}{$\begin{array}{l}\text { Dilution of } \\
\text { antiserum } \\
(n \text { in } \times 2 n)\end{array}$} & \multicolumn{8}{|c|}{ Dilution of antigen $(n$ in $\times 1000 \times 2 n)$} \\
\hline & 0 & 1 & 2 & 3 & 4 & 5 & 6 & $\infty$ \\
\hline
\end{tabular}

\begin{tabular}{|c|c|c|c|c|c|c|c|c|}
\hline 0 & + & + & + & + & + & + & - & - \\
\hline 1 & + & + & + & + & + & + & - & - \\
\hline 2 & + & + & + & + & + & + & - & - \\
\hline 3 & + & + & + & + & + & \pm & - & - \\
\hline 4 & + & + & + & + & \pm & - & - & - \\
\hline 5 & + & + & + & + & - & - & - & - \\
\hline 6 & - & - & - & - & - & - & - & - \\
\hline
\end{tabular}

The antiserum absorbed with pig serum

\begin{tabular}{|c|c|c|c|c|c|c|c|c|}
\hline 0 & + & + & + & + & - & - & - & - \\
\hline 1 & + & + & + & + & - & - & - & - \\
\hline 2 & + & + & + & + & - & - & - & - \\
\hline 3 & + & + & + & - & - & - & - & - \\
\hline 4 & - & - & - & - & - & - & - & - \\
\hline 5 & - & - & - & - & - & - & - & - \\
\hline 6 & - & - & - & - & - & - & - & - \\
\hline
\end{tabular}

B. The Reaction of the Same Antiserum, absorbed with Pig Serum, with Whole-Antigen and

Components of Pig Stomach Mucosa

The antiserum was used without dilution. - : negative reaction.

\begin{tabular}{|c|c|c|c|c|c|c|c|}
\hline \multirow{3}{*}{ Antigen } & \multicolumn{7}{|c|}{ Dilution of antigens } \\
\hline & \multicolumn{4}{|c|}{$\mathrm{n}$ in $\times 100 \times 2 \mathrm{n}$} & \multicolumn{3}{|c|}{$\mathrm{n}$ in $\times 1000 \times 2 \mathrm{n}$} \\
\hline & 0 & 1 & 2 & 3 & 0 & 1 & $\infty$ \\
\hline Whole-stomach mucosa-antigen & - & - & - & - & - & - & - \\
\hline Protein I & - & - & - & - & - & - & - \\
\hline Protein II & - & - & - & - & - & - & - \\
\hline PNA & - & - & 一 & 一 & - & - & 一 \\
\hline Polyuronic Acids & - & - & - & - & - & - & - \\
\hline Group Carbohydrate & - & - & - & - & - & - & - \\
\hline
\end{tabular}

of the tissue even at a dilution of the antigens of $1: 100$ (Table VIIIB).

3. Experiments similar to immediately above were carried out by replacing the anti-pig kidney (cortex)-serum for the anti-pig liver-serum 
TABLE X

A. Precipitin Reaction of Anti-Canine Gastric Mucosa-Rabbit Serum (I) with Whole-Canine Gastric Mucosa-Antigen -: negative reaction, \pm : faint $r .,+$ : definitely positive $r$.

\begin{tabular}{c|cccccccc}
\hline \multirow{2}{*}{$\begin{array}{c}\text { Dilution of } \\
\text { antiserum } \\
(\mathrm{n} \text { in } 2 \mathrm{n})\end{array}$} & \multicolumn{7}{|c}{ Dilution of antigen $(\mathrm{n}$ in $\times 1000 \times 2 \mathrm{n})$} \\
\cline { 2 - 8 } & 0 & 1 & 2 & 3 & 4 & 5 & 6 & $\infty$ \\
\hline \multicolumn{7}{c}{ The antiserum not absorbed } \\
\hline 1 & + & + & + & + & + & \pm & - & - \\
2 & + & + & + & + & + & \pm & - & - \\
3 & + & + & + & + & + & - & - & - \\
4 & + & + & + & + & + & - & - & - \\
5 & + & + & + & + & + & - & - & - \\
6 & - & \pm & \pm & \pm & - & - & - & - \\
& - & - & - & - & - & - & - & - \\
\hline 0 & The antiserum absorbed with dog serum & & \\
\hline & + & + & + & + & \pm & - & - & - \\
2 & + & + & + & + & \pm & - & - & - \\
3 & + & + & + & + & \pm & - & - & - \\
4 & + & + & + & \pm & - & - & - & - \\
5 & \pm & \pm & \pm & - & - & - & - & - \\
6 & - & - & - & - & - & - & - & - \\
& - & - & - & - & - & - & - & -
\end{tabular}

B. The Reaction of the Same Antiserum, absorbed with Dog Serum, with Whole-Antigen and Components of

Pig Stomach Mucosa

The antiserum was used without dilution. - : negative reaction, \pm : faint $r .,+$ : definitely positive $r$.

Figures in parentheses express antibody titre.

\begin{tabular}{|c|c|c|c|c|c|c|c|c|c|c|}
\hline \multirow{3}{*}{ Antigen } & \multicolumn{10}{|c|}{ Dilution of antigens } \\
\hline & \multicolumn{4}{|c|}{$\mathrm{n}$ in $\times 100 \times 2 n$} & \multicolumn{6}{|c|}{$n$ in $\times 1000 \times 2 n$} \\
\hline & 0 & 1 & 2 & 3 & 0 & 1 & 2 & 3 & 4 & $\infty$ \\
\hline $\begin{array}{l}\text { Whole-pig stomach } \\
\text { mucosa-antigen }\end{array}$ & + & + & + & + & $\stackrel{ \pm}{(4)}$ & - & - & - & - & - \\
\hline Protein I & $\begin{array}{l} \pm \\
(1)\end{array}$ & - & - & - & - & & & & & - \\
\hline Protein II & $\frac{ \pm}{(1)}$ & - & - & - & - & - & - & & & - \\
\hline PNA & + & + & + & + & + & + & + & & & \\
\hline Polyuronic Acids & \pm & $\stackrel{ \pm}{(1)}$ & - & - & - & - & - & - & & \\
\hline Group Carbohydrate & + & + & + & + & + & + & + & $\begin{array}{l} \pm \\
(1)\end{array}$ & - & \\
\hline
\end{tabular}


The results are embodied in Tables IXA and IXB. The antigen and antibody titre of the antiserum in the reaction with the Whole-kidney cortex-antigen were $1000 \times 2^{5}$ and $2^{5}$ respectively before absorption with pig serum and $1000 \times 2^{3}$ and $2^{3}$ respectively after the absorption. The antiserum absorbed with pig serum gave no positive precipitin reaction with the antigens of the pig stomach mucosa as above.

4. The precipitin reaction of the anti-canine gastric mucosa-sera

Whole-canine gastric mucosa-antigen reacted distinctly with the antisera, as such as well as after absorption with dog serum. Of the pig stomach mucosa components, Proteins I and II and Polyuronic Acids reacted only little with the antisera treated with dog serum, but, contrariwise, PNA and Group Carbohydrate eminently. Table X shows the results given by the antiserum $I$.

\section{Summary and Conclusion}

1. Rabbit antisera of the physiological saline extracts of stomach-, oesophagus-, duodenum-, small intestine- and colon-mucosa, liver and kidney-cortex of pig and of the canine gastric mucosa were prepared, and the serological tests of those sera with the extracts of those tissues and the components (proteins, pentosenucleic acid, polyuronic acids, group mucopolysaccharide, cold-alcohol soluble fraction) of pig gastric mucosa were carried out.

2. The anti-pig gastric mucosa serum, absorbed with pig serum, gave the serological (precipitin- and complement-fixing-) reactions not only with the saline extract and cold-alcohol soluble fraction of this mucosa but also with the saline extract of other pig tissues, the extract of the lower parts of the digestive tract reacting with strengths decreasing with the increase in distance of the parts from the stomach. After further absorption with the extract of pig oesophagus mucosa, it reacted with the gastric mucosa extract but not with those obtained from the other tissues. When the extract of the oesophagus mucosa was substituted with that of another part of the pig digestive tract for absorption, the absorbed serum gave precipitin reaction with the extracts of the various parts of the digestive tract (exclusive of the one used for absorption). And, when absorption was effected with the extract of pig liver besides pig serum, the antiserum lost the potency of giving the reaction with the extract of pig kidney and vice versa, but absorption with these extracts was of no influence upon the potency of the antiserum of giving the reaction with the extract of the other pig tissues.

3. The anti-pig gastric mucosa-serum absorbed with pig serum and oesophagus extract precipitated only the pentosenucleic acid among the water-soluble, high-molecular pig gastric mucosa components and, 
at that, at the same concentration of the nucleic acid as when the antiserum had been absorbed with pig serum alone. When absorbed with another pig tissue extract besides pig serum, the antiserum reacted also with the pig gastric mucosa components other than the pentosenucleic acid, intensity varying according to the absorbent as had been suggested by the precipitin reaction of the antiserum, absorbed with pig serum alone, with the extract of the other tissues, and the antigen dilution, where the pentosenucleic acid reacts, was not altered by any of the tissue extracts employed for absorption. The anti-pig gastric mucosa-serum after absorption with both pig serum and pig oesophagus mucosa extract did not give the complement-fixing reaction with the cold-alcohol soluble fraction of the pig gastric mucosa, unlike after absorption with pig serum alone. The findings are suspected to be an evidence that the pentosenucleic acid of the pig gastric mucosa is the sole antigen specific to this tissue.

4. The water-soluble pig gastric mucosa components did not give precipitin reaction with the anti-pig liver- and anti-pig kidney-serum, but did with the anti-canine gastric mucosa-serum absorbed with canine serum, the pentosenucleic acid and group carbohydrate reacting strongly and the proteins and polyuronic acids faintly.

5. Taken altogether, the pentosenucleic acid of gastric mucosa in general may be plausibly assumed to be extremely organ-specific in distinction from the other components of this tissue.

Through the Grant Committee for Scientific Researches was given a grant from the Education Department in aid to us, which is gratefully acknowledged. H. Masamune.

\section{References}

1) Tokutomi, Tohoku J. Exp. Med., this volume, p. 163. 